\title{
THE ROLE OF JOB CRAFTING ON THE PROMOTION OF FLOW AND WELLBEING*
}

\author{
RITA P. DE DEVOTTO ${ }^{1}$ \\ (iD) https://orcid.org/0000-0002-2287-2526 \\ CLARISSA P. P. FREITAS \\ (iD) https://orcid.org/0000-0002-2274-8728 \\ SOLANGE M. WECHSLER ${ }^{3}$ \\ (iD) https://orcid.org/0000-0002-9757-9113
}

To cite this paper: Pimenta de Devotto, R., Freitas, C. P. P., \& Wechsler, S. M. (2020). The role of job crafting on the promotion of flow and wellbeing. Revista de Administração Mackenzie, 21 (1), 1-24. doi:10.1590/1678-6971/eRAMD200113

Submission: June 10, 2019. Acceptance: Sept. 4, 2019.

* Credit goes to Wagner de Lara Machado for his help in planning data collection.

1 Faculdades de Campinas (Facamp), Campinas, SP, Brazil.

2 Universidade Salgado de Oliveira (Universo), Niterói, RJ, Brazil.

3 Pontifícia Universidade Católica de Campinas (PUC-Campinas), Campinas, SP, Brazil.

\section{(cc) BY




\section{ABSTRACT}

Purpose: To investigate the mediating role of flow at work on the relations of job crafting (task crafting, cognitive crafting and relational crafting) with positive mental health dimensions (emotional well-being, psychological well-being and social well-being).

Originality/value: The job crafting actions have been identified as antecedents of the levels of well-being at work. The present study contributed to the literature examining the relationships between job crafting, flow at work and positive mental health, not yet investigated in previous empirical studies.

Design/methodology/approach: The quantitative approach was used through an online questionnaire composed of a sociodemographic questionnaire and three scales. The sample consisted of 386 professionals from different Brazilian states, of which $58 \%$ were female, with a mean age of 44 years $(S D=12$ years). The data were analyzed through structural equations.

Findings: The results of the analysis of structural equations showed that relational crafting had a direct impact on positive mental health. The relations of cognitive crafting with positive mental health were totally mediated by flow at work. We concluded that job crafting, primarily cognitive crafting, influence occupational and general well-being.

\section{KEYWORDS}

Employee attitude. Flow. Job crafting. Mental health. Structural equation modelling. 


\section{INTRODUCTION}

Because of the current shift from manufacturing economies to service and knowledge economies, organizations must increase their ability to respond to external pressures to be innovative and competitive. Internally, uncertainty and interdependence between job functions, formally less defined than in the past, has grown, leading managers to require employees to take initiative at work by anticipating and creating changes in how work is performed (Grant \& Parker, 2009).

Traditional work designs defined by top-down management have been criticized for making workers passive recipients of their jobs (Wrzesniewski, LoBuglio, Dutton, \& Berg, 2013) and for producing inefficiencies and inadequacies between person-job fit. (e.g., low engagement, illness, underutilization of skills, meaninglessness at work) (Demerouti, 2014). In contrast, the theoretical perspective of job crafting (Wrzesniewski \& Dutton, 2001) has emphasized the active role of employees in shaping their own work experience, positioning itself as a plausible and promising alternative to traditional work design theories (Rudolph, Katz, Lavigne, \& Zacher, 2017). The phrase "redesenho do trabalho" (Chinelato, Ferreira \& Valentini, 2015; Pimenta de Devotto \& Wechsler, 2018) has been used in Brazilian Portuguese to refer to job crafting.

Job crafting encompasses employees' proactive actions to physically or cognitively alter tasks and relationships at work in order to align them with their values, positive strengths (e.g., skills, attributes and talents) and passions (Wrzesniewski \& Dutton, 2001; Berg, Dutton \& Wrzesniewski, 2013). Employees engage in job crafting 1. to build a more positive identity at work (Berg, Dutton, \& Wrzesniewski, 2008), 2. to satisfy basic psychological needs and to increase well-being (Slemp \& Vella-Brodrick, 2014; Slemp, Kern, \& Vella-Brodrick, 2015) and to optimize the level of job demands and job resources (Tims, Bakker \& Derks, 2012).

According to Wrzesniewski and Dutton (2001), individuals recreate their own work through three types of strategies: 1. task crafting (e.g., physical changes in number, scope, and type of tasks), 2. cognitive crafting (e.g., changes in the way an individual perceives his or her work), and 3. relational crafting (e.g., changes in interactions with peers, supervisors, clients, and suppliers). Within the job demands-resources model (Bakker \& Demerouti, 2016), job crafting has been proposed as a specific form of proactive behavior in which the individual initiates changes in the level of job 
demands (e.g., increasing challenging demands and decreasing hindering job demands) and in the level of job resources (e.g., increasing structural and social job resources) to improve the fit between his or her job and his or her needs and personal resources (Tims \& Bakker, 2010; Tims et al., 2012).

Job crafting is a predictor of work engagement (Bakker \& Demerouti, 2016). Work engagement is a positive mental state characterized by vigor, dedication and concentration at work and it has been considered an indicator of occupational health (Vazquez, Magnan, Pacico, Hutz, \& Schaufeli, 2015). Findings from a recent meta-analysis indicated the strong correlation $\left(r_{c}=\right.$ 0.45) of job crafting with work engagement (Rudolph et al., 2017). Interventions aimed at stimulating job crafting behaviors have produced increases in work engagement, especially when employees use strategies aimed at increasing job resources (Wingerden, Bakker, \& Derks, 2017) or modifying the meaning of work through cognitive crafting (Sakuraya, Shimazu, Imamura, Namba, \& Kawakami, 2016).

Job crafting also predicted other indices of well-being at work. Tims, Bakker, and Derks (2013) found in a longitudinal study that employees who increased their job resources had higher job satisfaction and decreased burnout. Job crafting has been suggested to be functional in mitigating the feeling of boredom at work and consequently minimizing its negative outcomes (e.g., depressive complaints, counterproductive work behaviors, distress) (Hooff \& Hooft, 2014). Slemp and Vella-Brodrick (2014) found that job crafting predicted the satisfaction of basic psychological needs (e.g., autonomy, competence, and relatedness), which, in turn, directly predicted the level of subjective well-being (e.g., positive affect and life satisfaction) and indirectly predicted psychological well-being (e.g., optimal functioning of the individual). Taken together, these findings suggest that job crafting may be a useful strategy for improving occupational well-being (e.g., work engagement, job satisfaction and decrease of burnout), as well as the overall well-being of employees (e.g., subjective well-being and psychological well-being).

Based on these findings, we propose that job crafting can create favorable conditions for employees to experience positive mental states at work and in life, in general. Among the indicators of occupational well-being, flow at work has been characterized as a relevant construct for assessing the emotional state of professionals (Demerouti \& Mäkikangas, 2017; Salanova, Martínez, Cifre, \& Schaufeli, 2005). Work-related flow can be described as a positive and transient state of mind, in which professionals are fully absorbed in performing their work activities, feel enjoyment and are intrinsically 
motivated to develop them (Demerouti, Bakker, Sonnentag, \& Fullagar, 2012). To the best of our knowledge, there is no previous empirical study that has investigated the relationship between the three job crafting strategies (Wrzesniewski \& Dutton, 2001) and flow at work.

Individual well-being has been mainly assessed from the hedonic (i.e., subjective well-being) (Diener, 1984) and eudaimonic perspectives (i.e., psychological well-being) (Ryff, 1989). Recently, it was noted that the evaluation of well-being by means of positive mental health (Keyes, 2002) has been increasingly valued in health research, which is an indicator of the integration and adaptation of the individual to his or her community (Sequeira et al., 2014). Positive mental health encompasses the assessment of emotional well-being (also identified as subjective well-being), psychological wellbeing and social well-being simultaneously (Keyes, 2002; Machado \& Bandeira, 2015), and it is therefore an effective measure of general wellbeing. Studies evaluating the relationship of job crafting strategies with positive mental health may contribute to the understanding of their beneficial effect on overall well-being.

Based on this research review, the present study contributed to the literature by examining: 1 . whether job crafting produces work-related flow, 2. whether job crafting directly contributes to the increase of positive mental health, and 3. whether the occurrence of flow at work mediates the relationship of job crafting with positive mental health. To the best of our knowledge, the relationships between these variables have not been investigated in previous empirical studies. In addition, this study provides evidence to support the development of job crafting as a management strategy that may increase levels of mental health at work through workrelated flow experiences.

\section{FLOW AT WORK}

Flow is a positive and intense mental state of short duration in which a person performing an activity is fully immersed in a feeling of energized focus and full devotion to the present moment and is enjoying it intensely (Csikszentmihalyi, 1996). In the work context, the flow state is similar to other experiences studied empirically in sports and in the arts (Salanova et al., 2005). Work-related flow can be experienced in any type of work because its occurrence depends more on the quality of the experience than on the nature of the activity (Demerouti \& Mäkikangas, 2017). Flow at work is 
defined as an intense short-peak experience at work characterized by absorption, enjoyment and intrinsic motivation. Absorption is characterized by a state of total concentration in which the individual is completely immersed in his or her work. The notion of time is distorted, and there is a momentary loss of self. Work enjoyment refers to feeling happy and making positive evaluations of the flow experience. Intrinsic motivation at work refers to performing an activity for its own sake and satisfaction, without necessarily seeking some extrinsic reward (Bakker, 2008).

Work-related flow levels were generally higher than the levels of flow experienced in active or passive leisure activities (Engeser \& Baumann, 2016). The occurrence of flow at work is related to the perception that an individual has about his or her ability to respond to challenging demands at work (Bakker, 2005). Concurrently, the variety and availability of job resources (e.g., autonomy, social support, opportunities for development) were positively related to work-related flow experiences (Mäkikangas, Bakker, Aunola, \& Demerouti, 2010) and fostered the occurrence of future flow at work (Salanova, Bakker, \& Llorens, 2006). Thus, the state of flow was most often experienced in work contexts that combined an abundance of job resources with challenging job demands (Bakker \& Woerkom, 2017; Demerouti \& Mäkikangas, 2017).

Proactive individual job redesign optimizes the level of job demands and job resources with individual needs at work (Tims et al., 2012). By shaping their own work experience, employees create opportunities to use abilities (e.g., skills, talents, competencies), to exert passions (e.g., intrinsic motivations) and to build meaning at work that is aligned with their personal values (Berg et al., 2013). In line with these perspectives, Bakker and Woerkom (2017) proposed that individuals can create their own workrelated flow experiences by using proactive individual strategies such as job crafting. Recent empirical findings have shown that task crafting predicted flow in millennial youth (i.e., dimension of work engagement) (Mihelič \& Aleksić, 2017). Accordingly, we suggest that the individual job redesign strategies that physically alter tasks (e.g., creating challenging demands, increasing structural job resources), relationships (e.g., increasing social job resources), and strategies that cognitively modify the perception of tasks and relationships are all strategies leading to flow at work. Therefore, we propose the following hypothesis:

- Hypothesis 1: Task crafting (1a), cognitive crafting (1b), and relational crafting (1c) are positively related to flow at work. 


\section{POSITIVE MENTAL HEALTH}

The hedonic perspective of well-being, also known as subjective or emotional well-being, emphasizes happiness, the preponderance of positive affect over negative affect, and overall life satisfaction (Diener, 1984). The eudaimonic perspective, or psychological well-being, proposes that wellbeing is achieved through optimal individual functioning in conjunction with the development of character strengths and virtues, and the selfactualization of potential (Ryff 1989). Subsequently, Keyes (2002) combined the hedonic concept of well-being and the psychological and societal aspects of eudaimonic well-being to make up the definition of positive mental health. Social well-being refers to a person's development of individual potential in relationships with others and his or her optimal functioning in community (Machado \& Bandeira, 2015). The construct of positive mental health (Keyes, 2002) has three dimensions (e.g., emotional well-being, psychological well-being and social well-being) and aligns with the three core components of the World Health Organization's definition of mental health: well-being, effective functioning of an individual, and effective functioning for a community (Machado \& Bandeira, 2015).

Research on the relationship of job crafting and occupational well-being has yielded positive results using primarily positive (e.g., work engagement) and negative (e.g., burnout) occupational indicators (Nielsen \& Abildgaard, 2012; Tims et al., 2013). Some studies have assessed the positive impact of job crafting on emotional well-being (Heuvel, Demerouti, \& Peeters, 2015; Hooff \& Hooft, 2014) and psychological well-being (Slemp \& Vella-Brodrick, 2014). However, the relationship between job crafting and social well-being, a component of positive mental health (Keyes, 2002), remains unexplored. Therefore, in line with these studies, we propose the following hypothesis:

- Hypothesis 2: Task crafting (2a), cognitive crafting (2b), and relational crafting (2c) are positively related to positive mental health (e.g., emotional well-being, psychological well-being and social well-being).

\section{JOB CRAFTING, FLOW AT WORK AND POSITIVE MENTAL HEALTH}

Job crafting is known to directly influence occupational well-being (e.g., work engagement) and broader well-being (e.g., subjective well-being and 
psychological well-being). By redesigning their own work, employees also facilitate the emergence of work-related flow experiences (Bakker \& Woerkom, 2017). The flow at work, a motivating and self-rewarding state of mind, is fostered by the individual's perception of the importance of its outcome (Engeser \& Baumann, 2016) and can be functional for his or her development at work (Bakker, 2005, 2008).

Demerouti et al. (2012) found that in the face of insufficient recovery after work breaks, work enjoyment (i.e., pleasurable dimension of flow at work) had a strong positive effect on vigor and a negative effect on exhaustion after a workday. This finding suggested that the positivity engendered by flow at work functioned as a substitute for insufficient work breaks and as a protective factor in dealing with the negative impact of high job demands (Demerouti et al., 2012). It has also been noted that various work-related flow experiences over time have strengthened personal resources (e.g., selfefficacy) (Salanova et al., 2006). Consistent with the hedonic and eudaimonic perspectives of well-being, these findings suggest that work-related flow may influence subjective well-being (e.g., presence of positive affect and decrease of negative affect) and psychological well-being (e.g., development of personal resources and resilience).

In addition, it was observed that the averages of flow at work were higher when individuals were immersed in core work activities, followed by activities in which they were necessarily relating to others at work (i.e., cooperation and communication) (Engeser \& Baumann, 2016). Thus, flow at work may also influence social well-being (e.g., developing positive relationships with others). While not necessarily a state of happiness, flow at work could be a key ingredient for a good life.

Flow experiences produce ephemeral positive effects on the individual, but lose their intensity by the end of the activity; thus, various flow experiences over time broaden and strengthen the self (Csikszentmihalyi, 1996). Work-related flow is expected to increase overall well-being. Therefore, we will investigate whether work-related flow, facilitated or produced by job crafting, is conducive to overall well-being:

- Hypothesis 3: Flow at work mediates the relationships of task crafting (3a), cognitive crafting (3b), and relational crafting (3c) to positive mental health (emotional well-being, psychological well-being and social well-being).

Therefore, we propose that flow at work mediates the relationships between job crafting and positive mental health. Thus, considering the 
different hypotheses formulated in the present study, our objective is to test the model presented in Figure 4.1.

\section{(Figure 4.1)}

\section{FLOW AT WORK AS A MEDIATOR OF THE RELATIONSHIPS OF JOB CRAFTING WITH THE POSITIVE MENTAL HEALTH DIMENSIONS}

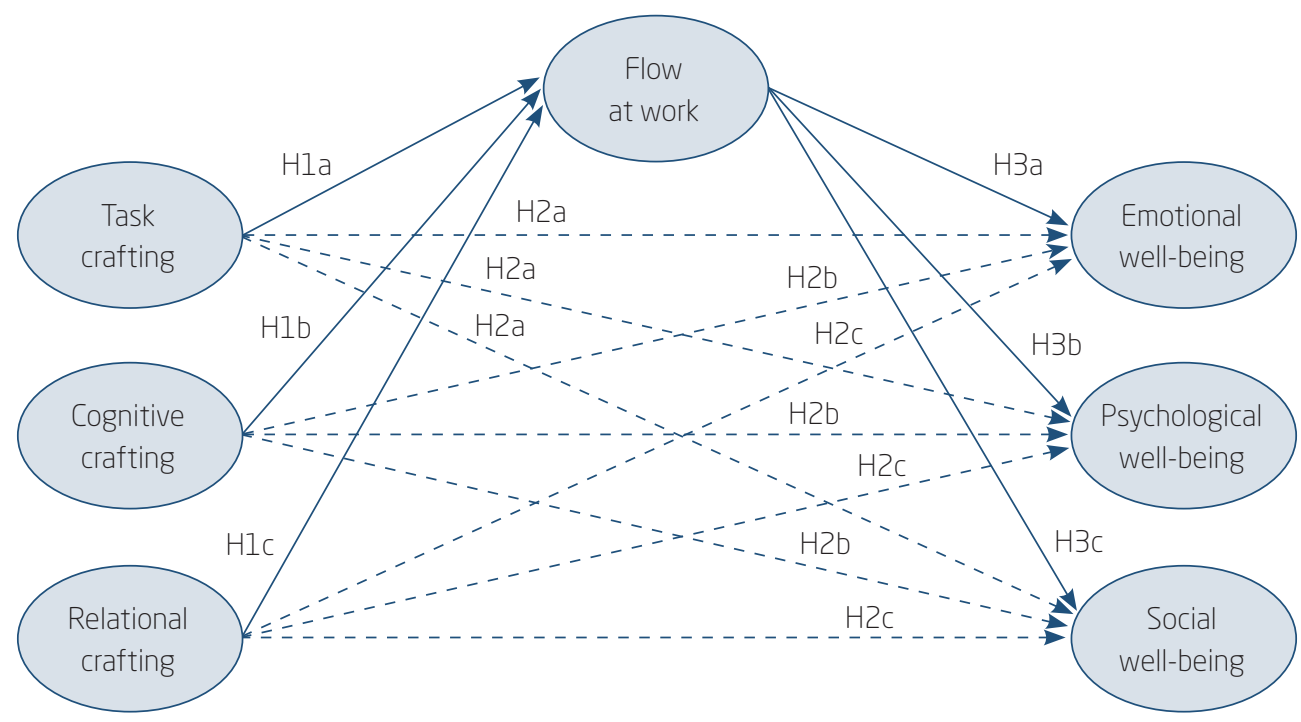

Source: Elaborated by the authors.

\section{METHOD}

\subsection{Participants}

In the present study, we used a convenience sample composed of 386 professionals from different Brazilian states, $58 \%$ female, aged between 18 and $78(M=44$ years of age, $S D=12$ years of age $)$. In this sample, $59 \%$ were married, $26 \%$ were single, $11 \%$ were divorced, $1 \%$ were widowed and $3 \%$ had other relationship types. The job tenure of the participants ranged from one to 50 years of experience $(M=10.4$ years of experience, $S D=10.2$ years of experience). Among the participants, $56 \%$ held a postgraduate degree, $30 \%$ had completed higher education, $7 \%$ were in a postgraduate program, $5 \%$ were attending higher education, and $3 \%$ had completed high school. 


\subsection{Instruments}

- Job Crafting Questionnaire (JCQ) (Slemp \& Vella-Brodrick, 2013, adapted to Brazilian Portuguese by Pimenta de Devotto \& Machado, 2017): consists of 15 items, answered on a Likert scale of six points ranging from "rarely" (1) to "very often" (6). The scale evaluates three dimensions (task crafting, $f c=0.80$; cognitive crafting, $f c=0.93$; and relational crafting, $f c=0.75$ ) and presents satisfactory reliability indices (Pimenta de Devotto \& Machado, 2017). The Cronbach's alpha and the fit indices in this sample were satisfactory, suggesting adjustment of the instrument: task crafting $(\alpha=0.76)$; cognitive crafting $(\alpha=0.91)$; and relational crafting, $(\alpha=0.82)$; CFI $=0.97$; TLI $=0.96$; RMSEA $(90 \%$ CI $)=0.08(0.07-0.09)$.

- Mental Health Continuum (Keyes, 2005, adapted to Brazilian Portuguese by Machado \& Bandeira, 2015): The scale consists of 14 items, answered on a six-point Likert scale, in which the extremes are "never" (1) and "everyday" (6). Three subscales were used to assess subjective or emotional well-being (three items), psychological well-being (six items), and social well-being (five items). The instrument presented internal consistency for the dimensions of positive mental health (emotional wellbeing, $\alpha=0.88$; psychological well-being, $\alpha=0.89$; and social well-being, $\alpha=0.85)$ and satisfactory fit indices (CFI $=0.96$; TLI $=0.95$; RMSEA $(90 \% \mathrm{CI})=0.10(0.09-0.11))$ in the present sample.

- Work-Related Flow Inventory -WOLF (Bakker, 2008, adapted to Brazilian Portuguese by Freitas, Damásio, Haddad, \& Koller, 2019): the scale consists of 13 items answered according to a seven-point Likert scale $(1=$ never to $7=$ always). Three subscales were used to assess absorption (four items), enjoyment (four items) and intrinsic motivation (five items). Items presented adequate internal consistency indices: absorption, $\alpha=$ 0.92; enjoyment, $\alpha=0.97$; and intrinsic motivation, $\alpha=0.87$ ) (Freitas et al., 2019). The inventory showed internal consistency $(\alpha=0.94)$ and satisfactory fit indices $(\mathrm{CFI}=0.93$; $\mathrm{TLI}=0.92$; $\mathrm{RMSEA}(90 \% \mathrm{CI})=$ $0.13(0.12-0.14)$ in the sample studied.

- Sociodemographic questionnaire: the instrument identifies the study sample in relation to demographic variables relevant to the research (e.g., gender and age).

\subsection{Data collection}

Data collection was carried out through an online questionnaire on the Survey Monkey platform that was disseminated in social and professional 
networks, as well as by the human resources department of a private organization of the services sector in the countryside of São Paulo State, for all its employees. This research was approved, in November of 2015, by the Research Ethics Committee of Pontfícia Universidade Católica de Campinas, under number Certificado de Apresentação para Apreciação Ética (Caae) no. 49694115.0.0000.5481. Confidentiality about the identity of the participants was guaranteed, as stated in the Informed Consent Form, according to Guidelines no. 466/2012 and earlier of the National Health Council.

\subsection{Data analysis}

Data analysis was performed by structural equation modeling using the weighted least squares mean and variance-adjusted (WLSMV) estimation method. The WLSMV estimation method was used because it is a robust estimation method for ordinal data (Muthén \& Muthén, 2010). The fit indices to evaluate the models were CFI $(>0.90)$, TLI $(>0.90)$, and RMSEA $(<0.08$, with $90 \%$ confidence interval not exceeding 0.10) (Brown, 2006). The bootstrapping technique (1,000 resamples) was used in all analyses performed in this study, and the $95 \%$ confidence interval of the effects of the investigated relationships was evaluated. All data analysis was performed with Mplus software version 6.12.

The three hypotheses proposed in this study were tested in three steps. The first step investigated whether job crafting performed as an antecedent to flow at work. In the second step, we investigated whether task crafting, cognitive crafting, and relational crafting were associated with positive mental health indices (emotional well-being, psychological well-being, and social well-being). Finally, in the third step, we evaluated whether flow at work mediated the relationships between task crafting, cognitive crafting, relational crafting with emotional well-being, psychological well-being and social well-being.

\section{RESULTS}

The first step of the analysis investigated hypothesis 1, which proposed that the three dimensions of job crafting contribute to the explanation of flow at work indices (task crafting, $\beta=0.16, \mathrm{EP}=0.04, p>0.00195 \% \mathrm{CI}=-0.01$ -0.32 ; cognitive crafting, $\beta=0.56, \mathrm{EP}=0.05, p<0.001,95 \% \mathrm{CI}=0.32-0.60$; 
and relational crafting, $\beta=0.09, \mathrm{EP}=0.06, p>0.001,95 \% \mathrm{CI}=-0.07-0.23$ ). The results showed that only the cognitive crafting dimension was directly associated with flow at work levels. Because the task crafting and relational crafting dimensions did not contribute significantly to the explanation of flow at work, a second model was tested, inserting only cognitive crafting and flow at work. Both variables presented a positive relationship of high magnitude (cognitive crafting, $\beta=0.63, \mathrm{EP}=0.03, p<0.001,95 \% \mathrm{CI}=$ $0.52-0.70)$. The adjustment indices were adequate for both models tested (model 1, $\chi^{2}(134)=1,926.13, \mathrm{p}<0.001 ; \mathrm{CFI}=0.92$; TLI $=0.91$; RMSEA $(90 \% \mathrm{CI})=0.19(0.18-0.19)$; and model $2, \chi^{2}(134)=2,192.62, p<0.001$; $\mathrm{CFI}=0.92 ; \mathrm{TLI}=0.91 ; \operatorname{RMSEA}(90 \% \mathrm{CI})=0.12(0.11-0.12))$.

To test hypothesis 2 , we investigated whether the three dimensions of job crafting contributed to the explanation of positive mental health levels. Only the cognitive crafting dimension $(\beta=0.46, \mathrm{EP}=0.08 ; p<0.001,95 \%$ $\mathrm{CI}=0.20-0.64)$ and relational crafting $(\beta=0.23$, $\mathrm{EP}=0.08, p<0.001$, $95 \% \mathrm{CI}=0.04-0.44)$ explained the levels of emotional well-being. The same pattern of relationships was observed for psychological well-being, in which the cognitive crafting dimension $(\beta=0.40, \mathrm{EP}=0.07, p<0.001$, $95 \% \mathrm{CI}=0.15-0.53)$ and relational crafting $(\beta=0.28, \mathrm{EP}=0.08, p<$ $0.001,95 \% \mathrm{CI}=0.15-0.60)$ contributed to explaining that dimension. The social well-being dimension also presented relationships of medium magnitude with the cognitive crafting dimensions $(\beta=0.41, \mathrm{EP}=0.07, p<0.001$, $95 \% \mathrm{CI}=0.17-0.53)$ and relational crafting $(\beta=0.35, \mathrm{EP}=0.08, p<$ $0.001,95 \% \mathrm{CI}=0.15-0.55)$. The task crafting dimension did not yield statistically significant contributions to explain the three dimensions of positive mental health (psychological well-being, $\beta=-0.05$, $\mathrm{EP}=0.10 ; p>$ $0.001,95 \% \mathrm{CI}=-0.31-0.21$; emotional well-being, $\beta=0.04$, $\mathrm{EP}=0.08$; $p>0.001,95 \% \mathrm{CI}=-0.18-0.25$; and social well-being, $\beta=-0.02$, $\mathrm{EP}=$ $0.08 ; p>0.001,95 \% \mathrm{CI}=-0.23-0.18)$.

Because the task crafting dimension did not contribute to the explanation of positive mental health, a second model was carried out to evaluate the direct effects of cognitive crafting and relational crafting on the dimensions of positive mental health. The results showed that these two dimensions made significant contributions of medium size magnitude in explaining levels of emotional well-being, psychological well-being and social well-being. The first model $\left(\chi^{2}(362)=1,034.27, p<0.001\right.$; CFI $=0.95$; TLI $=0.95$; RMSEA $(90 \% \mathrm{CI})=0.07(0.06-0,07))$ and the second model $\left(\chi^{2}(242)=852.45\right.$, $p<0.001 ; \mathrm{CFI}=0.95 ; \mathrm{TLI}=0.95 ; \mathrm{RMSEA}(90 \% \mathrm{CI})=0.8(0.07-0.09))$ presented adequate adjustment indices. 
The third hypothesis proposed that the relationships of job crafting with positive mental health levels would be mediated by flow at work. However, based on the results of the analysis in the previous steps, this hypothesis was reformulated. Thus, we evaluated whether flow at work mediated the relationship of the cognitive crafting dimension with positive mental health indices and whether the relational crafting dimension contributed to the explanation of emotional well-being, psychological well-being and social well-being. The results showed that flow at work fully mediated the relationship of cognitive crafting dimension $(\beta=0.75, \mathrm{EP}=0.03, p<0.001$, $95 \% \mathrm{CI}=0.21-0.43$ ), with positive mental health levels (emotional wellbeing, $\beta=0.54, \mathrm{EP}=0.10 ; \mathrm{p}<0.001,95 \% \mathrm{CI}=0.36-0.89$; psychological well-being, $\beta=0.44$, EP $=0$, 09; $p<0.001,95 \% \mathrm{CI}=0.23-0.69$, and social well-being, $\beta=0.32$, $\mathrm{EP}=0.09 ; p<0.001,95 \% \mathrm{CI}=0.14-0.65$ ) (see Figure 6.1). The relational crafting dimension contributed to explaining higher levels of emotional well-being $(\beta=0.19$, EP $=0.08 ; p<0.001,95 \%$ $\mathrm{CI}=0.09$ - 0.39), psychological well-being $(\beta=0.27$, EP $=0.08 ; p<0.001$, $95 \% \mathrm{CI}=0.02-0.45)$ and social well-being $(\beta=0.33$, EP $=0.09 ; p<$ $0.001,95 \% \mathrm{CI}=0.11-0.59$ ) (see Figure 6.1 ). In addition, the dimensions of positive mental health were positively related to each other (emotional well-being with psychological well-being, $r=0.64$, PE $=0.03$; $p<0.001$, $95 \% \mathrm{CI}=0.14-0.28$; psychological well-being with social well-being, $r=$ $0.49, \mathrm{EP}=0.03 ; p<0.001,95 \% \mathrm{CI}=0.10-0.24$; and emotional well-being with social well-being $r=0.42$, $\mathrm{EP}=0.03, p<0.001,95 \% \mathrm{CI}=0.09-0.24$ ). The fit indices of this model were satisfactory $\left(\chi^{2}(615)=2,957.69\right.$; CFI $=$ 0.92; TLI $=0.91$; RMSEA $(90 \% \mathrm{CI})=0.10(0.09-0.10))$, indicating the adequacy of the model. 


\section{(Figure 6.1)}

\section{FINAL MEDIATIONAL MODEL WITH STANDARDIZED PARAMETERS}

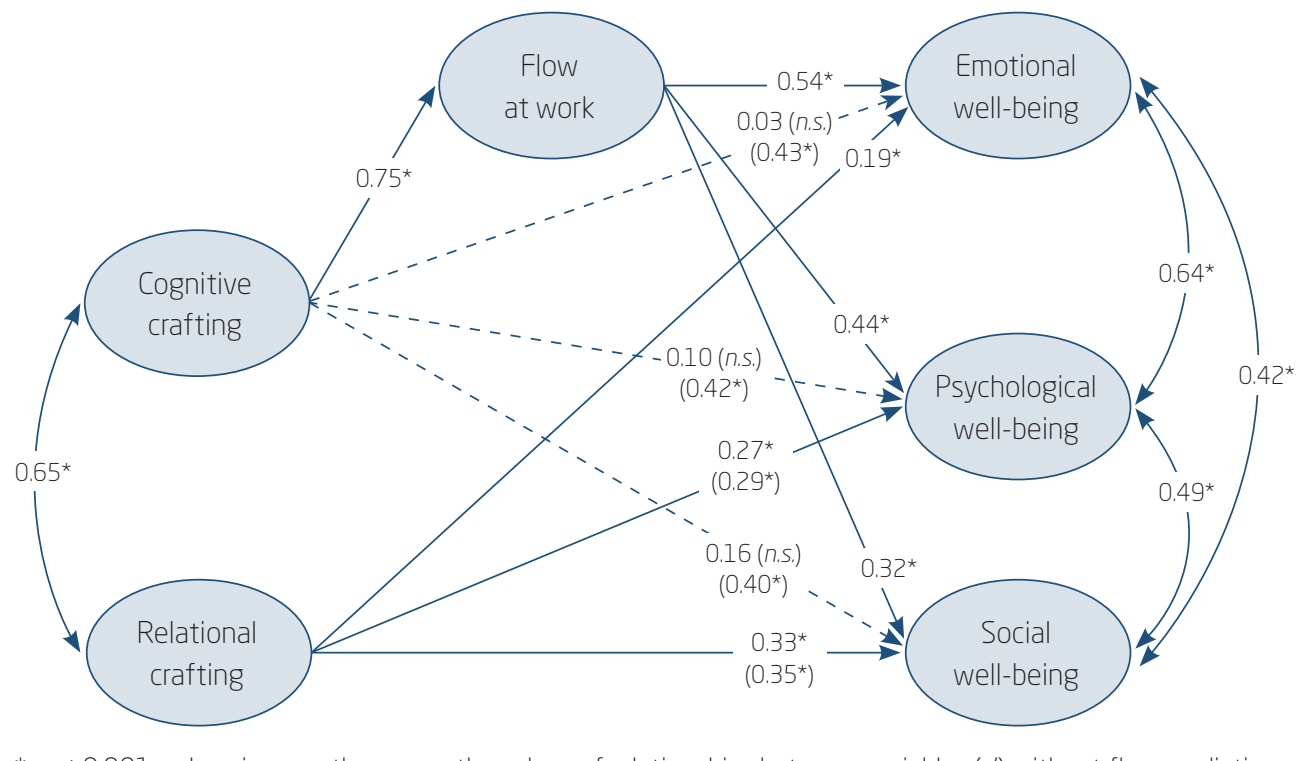

* $p<0.001$; values in parentheses are the values of relationships between variables ( $\left.c^{\prime}\right)$ without flow mediation.

Source: Elaborated by the authors.

\section{DISCUSSION}

Given the perspective of individual job redesign as a viable strategy for obtaining positive outcomes at work (Rudolph et al., 2017), the aims of the present study were to investigate the influence of the three job crafting strategies (Wrzesniewski \& Dutton, 2001) on work-related flow (hypothesis 1 ) and on positive mental health (hypothesis 2) and to test whether the occurrence of flow at work mediated the relationship of job crafting with positive mental health (hypothesis 3 ). Our findings partially corroborated these three hypotheses.

Our findings reinforced the proposition that individuals can create their own work-related flow experiences by means of job crafting (Bakker \& Woerkom, 2017). However, considering the three dimensions of job crafting, only the dimension of cognitive crafting exerted a moderate positive influence on flow at work. Contrary to our expectations, tangible individual job redesign behaviors, such as task and relationship crafting, did not have a direct and significant impact on the occurrence of flow at work. This result 
suggests that flow at work, a positive and intense mental state of short duration (Bakker, 2008), depends more on intangible changes (Lichtenthaler \& Fischbach, 2016) than on physical changes made by employees to tasks and relationships at work.

The importance of the cognitive crafting dimension of job crafting was also noted in relation to positive mental health. Hypothesis 2 predicted that task crafting (2a), cognitive crafting (2b), and relational crafting (2c) would be positively related to positive mental health. The results showed that cognitive crafting made a significant contribution of an average magnitude in explaining the dimensions of positive mental health, while relational crafting had a low-magnitude, but a significant influence on the dimensions of positive mental health. Thus, hypotheses (2b) and (2c) were corroborated. Contrary to hypothesis $2 \mathrm{a}$, task crafting did not contribute to overall wellbeing. Therefore, our results provide new evidence about the preponderant role of cognitive crafting in relation to other job crafting strategies.

Previous studies have provided evidence of the beneficial role of job crafting on subjective well-being and psychological well-being (Slemp \& Vella-Brodrick, 2015; Tims et al., 2012; Heuvel et al., 2015). However, the influence of job crafting on social well-being was unknown. Our findings demonstrated that individuals who cognitively crafted their work or changed their relationships at work experienced more social well-being. Specifically, the positive impact of increased levels of relational crafting on positive mental health demonstrated that employees who sought to develop positive relationships with their superiors and coworkers experienced higher levels of well-being, possibly because such crafting actions expanded their social job resources (e.g., social support, supervisor support). Individuals with high levels of social well-being have positive perceptions about the functioning of society, feel part of a community and contribute to its development (Machado \& Bandeira, 2015). The relationships revealed in this study can be understood by observing that, in a collectivist culture such as Brazil (Minkov et al., 2017), employees who perceive having higher levels of social support at work may experience a greater number of positive work experiences, rely on peer support in different situations and perceive their lives as successful.

Job crafting takes place within the organizational boundaries of work (Wrzesniewski \& Dutton, 2001) to change levels of job demands and job resources (Tims et al., 2012) or to satisfy the basic psychological needs of employees (Slemp \& Vella-Brodrick, 2015). However, our findings suggest that job crafting outcomes go beyond the work context. Taking the direct 
effects of cognitive crafting and relational crafting on the three dimensions of positive mental health, we concluded that job crafting can influence the broader and more permanent state of well-being. Job crafting contributes to hedonic and eudaimonic well-being, as well as to social well-being.

Finally, we found that flow at work, primarily produced by cognitive crafting, completely mediated the relationship of this dimension of job crafting with positive mental health. This finding fully corroborated hypothesis $3 \mathrm{~b}$. Individuals who cognitively crafted their own work experienced higher levels of flow at work, which, in turn, contributed to their emotional, psychological and social well-being. As noted before, and contrary to our expectations, task crafting did not contribute to promoting flow at work or influence positive mental health. Thus, hypothesis 3 a was refuted. Relational crafting did not contribute to the occurrence of work-related flow, but it exerted a low-magnitude, but significant influence on the three dimensions of positive mental health.

Cognitive crafting changes employees' perceptions of their own work to make it more meaningful and rewarding (Berg et al., 2013). Employees who engage in cognitive crafting often think about how their work brings meaning and purpose to life and how it contributes to their personal development and well-being. Moreover, job crafters keep in mind the value of their contributions to an organization's success and to their community's interests (Slemp \& Vella-Brodrick, 2014). Scholars have suggested that cognitive crafting is the job crafting dimension that most closely aligns with the construction of a positive identity and meaning at work. Concurrently, organizations have an ethical and moral obligation to establish conditions that foster meaningful work (Michaelson, Pratt, Grant, \& Dunn, 2014). Therefore, work conditions that facilitate job crafting should be promoted, especially those that stimulate cognitive crafting, because it has the potential to bring positive outcomes for employees and organizations.

Our findings called attention to the preponderant role of cognitive crafting, an intangible dimension of individual job redesign, in the promotion of work-related flow. The job crafting scale (JCS) (Tims et al., 2012), which is the most widely used job crafting instrument among researchers (Rudolph et al., 2017), operationalized job crafting in self-initiated behaviors of employees willing to make actual changes in the level of their job demands or job resources (Tims and Bakker, 2012), but it excludes the cognitive crafting dimension of the construct (Slemp \& Vella-Brodrick, 2013). In the validation study of the job crafting questionnaire (Slemp \& Vella Brodrick, 2013) adapted to the Brazilian context, the authors found that cognitive 
crafting was the most salient dimension of the construct compared to task and relational crafting. In the Brazilian sample, cognitive crafting showed the highest internal consistency, had precedence in the extraction of factors and explained a greater variance (Pimenta de Devotto, 2016). Empirical studies that evaluated the contribution of cognitive crafting to positive outcomes at work are scarce (Niessen, Weseler, \& Kostova, 2016). Therefore, we suggest that the role of cognitive crafting should not be neglected when evaluating job crafting, and it deserves more attention from researchers.

The inclusion of the cognitive crafting dimension in the job crafting assessment allowed us to evaluate the temporal sequence of individual job redesign actions (Slemp \& Vella-Brodrick, 2013). Our findings suggested that cognitive crafting may precede task and relational crafting. Once individuals have reformulated the meaning of their work, they should be better able to engage in tangible task crafting (e.g., adding new tasks to their work, changing the scope of tasks), as well as to make changes in the quantity and quality of work interactions. Sakuraya et al. (2016) found that, after an intervention program that stimulated job crafting behaviors in professionals in Japan, cognitive crafting significantly improved, but task and relational crafting did not. According to the authors, it may take a shorter time for employees to craft their own jobs cognitively and a longer time to craft their tasks and relationships at work. Task or relational crafting generate actual job changes, such crafting strategies may take more time to happen or require specific skills to be accomplished (Sakuraya et al., 2016).

In line with this perspective, Wrzesniewski et al. (2013) proposed three archetypal paths through which meanings and identities at work can lead to individual job redesign or be a result of it. Two archetypal pathways, alignment crafting (i.e., the pursuit of alignment between self and work) and aspirational crafting (i.e., changes in task and relationships to meet aspirations), would be driven by an a priori positive meaning and identity at work. The third archetypal pathway, called accidental crafting, is a process in which job crafting leads to an unintended discovery of more positive meaning at work. Therefore, in two of these three archetypal pathways, the cognitive crafting dimension precedes the tangible changes in tasks and relationships. Future studies can test the temporal sequence of the three job crafting strategies and investigate the factors and conditions, contributing to the different types of job crafting.

Despite its contributions, our research had three limitations. First, the exclusive use of self-report instruments may have produced bias related to the data collection method, so data need be analyzed with caution. The 
second limitation refers to the use of a sample by convenience, which resulted in a highly educated sample. Sample characteristics and sample by convenience may limit the generalization of results to other types of research. Finally, the relationships between well-being and other types of variables, such as personality traits, personal resources and job demands, were not assessed. The lack of evaluation of such variables makes it difficult to generalize the results, as these variables are related to occupational wellbeing (Demerouti, Bakker, \& Gevers, 2015; Demerouti et al., 2012) and general well-being. (e.g., positive mental health) (Machado \& Bandeira, 2015).

Regardless of these limitations, our study is of theoretical and practical relevance, as it demonstrated the role of job crafting in promoting workrelated flow and positive mental health. Future studies should investigate whether these relationships are replicated in occupational groups with different educational levels. In addition, longitudinal studies may uncover whether job crafting is a predictor of different well-being states (e.g., workrelated flow and positive mental health). Future research should contribute to the development of work-related interventions to promote occupational well-being and positive mental health.

\section{O PAPEL DO REDESENHO DO TRABALHO NA PROMOÇÃO DO FLOWE DO BEM-ESTAR}

\section{RESUMO}

Objetivo: Investigar o papel mediador do flow no trabalho entre as relações das dimensões de redesenho no trabalho (redesenho da tarefa, reformulação cognitiva e redesenho das relações) com as dimensões de saúde mental positiva (bem-estar emocional, bem-estar psicológico e bem-estar social).

Originalidade/valor: As ações de redesenho no trabalho têm sido valorizadas como antecedentes do bem-estar laboral dos profissionais. O presente estudo contribuiu para a literatura ao examinar as relações entre as ações de redesenho no trabalho, o flow no trabalho e a saúde mental positiva, ainda não investigadas em trabalhos empíricos prévios.

Design/metodologia/abordagem: Utilizou-se a abordagem quantitativa por meio de um questionário on-line composto por questionário socio- 
demográfico e três escalas. A amostra foi composta por 386 profissionais de diferentes estados brasileiros, sendo $58 \%$ do gênero feminino, com idade média de 44 anos ( $D P=12$ anos). Os dados foram analisados por meio de equações estruturais.

Resultados: Os resultados das análises de equações estruturais demonstraram que o redesenho das relações apresentou um impacto direto sobre a saúde mental positiva. As relações da reformulação cognitiva com a saúde mental positiva foram totalmente mediadas pelos níveis de flow no trabalho. Conclui-se que as ações de redesenho do trabalho, primordialmente a reformulação cognitiva, influenciam o bem-estar laboral e geral.

\section{$\int$ PALAVRAS-CHAVE}

Atitudes dos empregados. Flow. Redesenho do trabalho. Saúde mental. Modelo de equações estruturais.

\section{)}

\section{REFERENCES}

Chinelato, R. S. D. C., Ferreira, M. C., \& Valentini, F. (2015). Evidence of validity of the Job Crafting Behaviors Scale. Paidéia, 25(62), 325-332. doi:10.1590/1982-43272562201506

Csikszentmihalyi, M. (1996). Creativity: Flow and the psychology of discovery and invention. New York: HarperCollins.

Bakker, A. B. (2005). Flow among music teachers and their students: The crossover of peak experiences. Journal of Vocational Behavior, 66, 26-44. doi:10.1016/j.jvb.2003.11.001

Bakker, A. B. (2008). The work-related flow inventory: Construction and initial validation of the WOLF. Journal of Vocational Behavior, 72, 400-414. doi:10.1016/j.jvb.2007.11.007

Bakker, A. B., \& Demerouti, E. (2016). Job demands-resources theory: Taking stock and looking forward. Journal of Occupational Health Psychology, 22(3), 273-285. doi:10.1037/ocp0000056

Bakker, A. B., \& Woerkom, M. van (2017). Flow at work: A self-determination perspective. Occupational Health Science, 1-19. doi:10.1007/s41542017-0003-3 
Berg, J. M., Dutton, J. E., \& Wrzesniewski, A. (2008). What is job crafting and why does it matter. Recuperado de http://positiveorgs.bus.umich. edu/wp-content/uploads/What-is-Job-Crafting-and-Why-Does-itMatter1.pdf

Berg, J. M., Dutton, J. E., \& Wrzesniewski, A. (2013). Job crafting exercise. Ann Arbor: Regents of the University of Michigan.

Brown, T. A. (2015). Confirmatory factor analysis for applied research. Methodology in the social sciences (2nd ed.). New York: The Guilford Press.

Demerouti, E. (2014). Design your own job through job crafting. European Psychologist, 19(4), 237-247. doi:10.1027/1016-9040/a000188

Demerouti, E., \& Bakker, A. B. (2014). Job crafting. In M. C.W. Peeters, J. de Jonge, \& T. W. Taris (Eds.). An introduction to contemporary work psychology (pp. 414-433). Sussex, UK: Wiley Blackwell.

Demerouti, E., Bakker, A. B., \& Gevers, J. M. (2015). Job crafting and extrarole behavior: The role of work engagement and flourishing. Journal of Vocational Behavior, 91, 87-96.

Demerouti, E., Bakker, A. B., Sonnentag, S., \& Fullagar, C. J. (2012). Workrelated flow and energy at work and at home: A study on the role of daily recovery. Journal of Organizational Behavior, 33(2), 276-295. doi:10.1002/ job.760

Demerouti, E., \& Mäkikangas, A. (2017). What predicts flow at work?: Theoretical and empirical perspectives. In C. Fullagar \& A. Delle Fave (Eds.). Flow at work: Measurement and implications (pp. 66-80). Abingdon, Oxon, UK: Routledge Taylor \& Francis Group.

Diener, E. (1984). Subjective well-being. Psychological Bulletin, 95(3), 542-575. doi:10.1037/0033-2909.95.3.542

Engeser, S., \& Baumann, N. (2016). Fluctuation of flow and affect in everyday life: A second look at the paradox of work. Journal of Happiness Studies, 17(1), 105-124. doi:10.1007/s10902-014-9586-4

Freitas, C. P. P., Damásio, B. F., Haddad, E. J., \& Koller, S. H. (2019). WorkRelated Flow Inventory: Evidence of validity of the Brazilian Version. Paidéia, 29, e2901. doi:10.1590/1982-4327e290

Grant, A. M., \& Parker, S. K. (2009). Redesigning work design theories: The rise of relational and proactive perspectives. The Academy of Management Annals, 3(1), 317-375. doi:10.1080/19416520903047327

Heuvel, M. van den, Demerouti, E., \& Peeters, M. C. W. (2015). The job crafting intervention: Effects on job resources, self-efficacy, and affective well-being. Journal of Occupational and Organizational Psychology, 88(3), 511-532. doi:10.1111/joop.12128 
Hooff, M. L. van, \& Hooft, E. A. van (2014). Boredom at work: Proximal and distal consequences of affective work-related boredom. Journal of Occupational Health Psychology, 19(3), 348-359. doi:10.1037/a0036821

Keyes, C. L. M. (2002). The mental health continuum: From languishing to flourishing in life. Journal of Health and Social Research, 43(2), 207-222. doi:10.2307/3090197

Keyes, C. L. M. (2005). Mental illness and/or mental health? Investigating axioms of the complete state model of health. Journal of Consulting and Clinical Psychology, 73(3), 539-548. doi:10.1037/0022-006X.73.3.539

Lichtenthaler, P. W., \& Fischbach, A. (2016). The conceptualization and measurement of job crafting. Zeitschrift für Arbeits-und Organisationspsychologie AEO, 60, 173-186. doi:10.1026/0932-4089/a000219

Machado, W. L., \& Bandeira, D. R. (2015). Positive Mental Health Scale: Validation of the Mental Health Continuum-Short Form. Psico-USF, 20(2), 259-274. doi:10.1590/1413-82712015200207

Mäkikangas, A., Bakker, A. B., Aunola, K., \& Demerouti, E. (2010). Job resources and flow at work: Modelling the relationship via latent growth curve and mixture model methodology. Journal of Occupational and Organizational Psychology, 83(3), 795-814.

Michaelson, C., Pratt, M. G., Grant, A. M., \& Dunn, C. P. (2014). Meaningful work: Connecting business ethics and organization studies. Journal of Business Ethics, 121 (1), 77-90. doi:10.1007/s10551-013-1675-5.

Mihelič, K. K., \& Aleksić, D. (2017). "Dear employer, let me introduce myself"- flow, satisfaction with work-life balance and millennials' creativity. Creativity Research Journal, 29(4), 397-408. doi:10.1080/104004 19.2017.1376503

Minkov, M., Dutt, P., Schachner, M., Morales, O., Sanchez, C., Jandosova, J., Khassenbekov, Y., \& Mudd, B. (2017). A revision of Hofstede's individualismcollectivism dimension: A new national index from a 56-country study. Cross Cultural \& Strategic Management, 24(3), 386-404. doi:10.1108/CCSM11-2016-0197

Muthén, L. K., \& Muthén, B. O. (2015). Mplus user's guide: Statistical analysis with latent variables (7th ed.). Los Angeles: Muthén \& Muthén.

Nielsen, K., \& Abildgaard, J. S. (2012). The development and validation of a job crafting measure for use with blue-collar workers. Work $\mathcal{E}$ Stress: An International Journal of Work, Health and Organizations, 26(4), 365-384. doi:10.1080/02678373.2012.733543 
Niessen, C., Weseler, D., \& Kostova, P. (2016). When and why do individuals craft their jobs? The role of individual motivation and work characteristics for job crafting. Human Relations, 69(6), 1287-1313. doi:10.1177/00187 26715610642

Pimenta de Devotto, R. (2016). Adaptação e validação do Questionário de Job Crafting e sua relação com estados positivos no trabalho. (Dissertação de mestrado, Pontifícia Universidade Católica de Campinas, Campinas, SP, Brasil). Retrieved from http://tede.bibliotecadigital.puc-campinas.edu.br:8080/ jspui/handle/tede/906

Pimenta de Devotto, R., \& Machado, W. D. L. (2017). Job crafting: Uma revisão da produção científica internacional. Psico-USF, 22(3), 413-423. doi:10.15 90/1413-82712017220303

Pimenta de Devotto, R., \& Wechsler, S. M. (2018). Job crafting: Conceituação e qualidade científica das medidas. Avaliação Psicológica, 17(3), 351-361. doi:10.15689/ap.2018.1703.14335.08

Rudolph, C. W., Katz, I. M., Lavigne, K. N., \& Zacher, H. (2017). Job crafting: A meta-analysis of relationships with individual differences, job characteristics, and work outcomes. Journal of Vocational Behavior, 102, 112-138. doi:10.1016/j.jvb.2017.05.008

Ryff, C. D. (1989). Happiness is everything, or is it? Explorations on the meaning of psychological well-being. Journal of Personality and Social Psychology, 57(6), 1069-1081. doi:10.1037/0022-3514.57.6.1069

Sakuraya, A., Shimazu, A., Imamura, K., Namba, K., \& Kawakami, N. (2016). Effects of a job crafting intervention program on work engagement among Japanese employees: A pretest-posttest study. BMC Psychology, 4, Article ID 49. doi:10.1186/s40359-016-0157-9

Salanova, M., Bakker, A. B., \& Llorens, S. (2006). Flow at work: Evidence for an upward spiral of personal and organizational resources. Journal of Happiness Studies, 7(1), 1-22. doi:10.1007/s10902-005-8854-8

Salanova, M., Martínez, I., Cifre, E., \& Schaufeli, W. B. (2005). ¿Se pueden vivir experiencias óptimas en el trabajo? Analizando el flow en contextos laborales. Revista de Psicología General y Aplicada, 58(1), 89-100. Recuperado de https://dialnet.unirioja.es/servlet/articulo? codigo $=1335343$

Sequeira, C., Carvalho, J. C., Sampaio, F., Sá, L., Lluch-Canut, T., \& Roldán-Merino, J. (2014). Avaliação das propriedades psicométricas do Questionário de Saúde Mental Positiva em estudantes portugueses do ensino superior. Revista Portuguesa de Enfermagem de Saúde Mental, (11), 45-53. Recuperado de http://www.scielo.mec.pt/scielo.php? script $=$ sci abstract\&pid $=$ S1647-21602014000200007\&lng $=$ pt\&nrm $=$ iso 
Slemp, G. R., \& Vella-Brodrick, D. A. (2013). The Job Crafting Questionnaire: A new scale to measure the extent to which employees engage in job crafting. International Journal of Wellbeing, 3(2), 126-146. doi:10.5502/ijw. v3i2.1

Slemp, G. R., \& Vella-Brodrick, D. A. (2014). Optimising employee mental health: The relationship between intrinsic need satisfaction, job crafting, and employee well-being. Journal of Happiness Studies, 15(4), 957-977. doi:10.1007/s10902-013-9458-3

Slemp, G. R., Kern, M.L. \& Vella-Brodrick, D. A. (2015). Workplace WellBeing: The Role of Job Crafting and Autonomy Support. Psychology of Well-Being, 5(7). doi:10.1186/s13612-015-0034-y

Tims, M., \& Bakker, A. B. (2010). Job crafting: Towards a new model of individual job redesign. SA Journal of Industrial Psychology, 36(2), 1-9. doi:10.4102/sajip.v36i2.841

Tims, M., Bakker, A. B., \& Derks, D. (2012). Development and validation of the job crafting scale. Journal of Vocational Behavior, 80(1), 173-186. doi:10.1016/j.jvb.2011.05.009

Tims, M., Bakker, A. B., \& Derks, D. (2013). The impact of job crafting on job demands, job resources, and well-being. Journal of Occupational Health Psychology, 18(2), 230-240. doi:10.1037/a0032141

Vazquez, A. C. S., Magnan, E. D. S., Pacico, J. C., Hutz, C. S., \& Schaufeli, W. B. (2015). Adaptation and validation of the Brazilian version of the Utrecht Work Engagement Scale. Psico-USF, 20(2), 207-217. doi:10.1590/141382712015200202

Wingerden, J. van, Bakker, A. B., \& Derks, D. (2016). A test of a job demandsresources intervention. Journal of Managerial Psychology, 31(3), 686-701. doi:10.1108/JMP-03-2014-0086

Wingerden, J. van, Bakker, A. B., \& Derks, D. (2017). Fostering employee well-being via a job crafting intervention. Journal of Vocational Behavior, 100, 164-174. doi:10.1016/j.jvb.2017.03.008

Wrzesniewski, A., \& Dutton, J. E. (2001). Crafting a job: Revisioning employees as active crafters of their work. Academy of Management Review, 26(2), 179-201. doi:10.5465/AMR.2001.4378011

Wrzesniewski, A., LoBuglio, N., Dutton, J. E., \& Berg, J. M. (2013). Job crafting and cultivating positive meaning and identity in work. In A. B. Bakker (Ed.). Advances in positive organizational psychology (pp. 281-302). Bingley, UK: Emerald Publishing Group. doi:10.1590/1413-827120152 00202 


\section{J Arrtoen orts}

Rita P. de Devotto, master by the Department of Psychology, Catholic Pontifical University of Campinas (PUC-Campinas); Clarissa P. P. Freitas, Ph.D. by the Department of Psychology, Federal University of Rio Grande do Sul (UFRGS); Solange M. Wechsler, Ph.D. by the Department of Psychology, University of Georgia (UGA).

Rita P. de Devotto is now professor of Business Administration at the Faculdades de Campinas (Facamp); Clarissa P. P. Freitas is now professor at the Postgraduate Program in Psychology a of Salgado de Oliveira University (Universo); Solange M. Wechsler is now professor at the Department of Psychology of Catholic Pontifical University of Campinas (PUC-Campinas).

Correspondence concerning this article should be addressed to Rita P. de Devotto, Avenida Alan Turing, 805, Cidade Universitária, Campinas, São Paulo, Brazil, CEP 13083-898.

E-mail: rita.pimenta@facamp.com.br

\section{EDITORIAL BOARD}

Editors-in-chief

Janette Brunstein

Silvia Marcia Russi de Domênico

Associated Editor

Mary Sandra Carlotto

Technical Support

Vitória Batista Santos Silva

\section{EDITORIAL PRODUCTION}

Publishing Coordination

Jéssica Dametta

Layout Designer

Emap

Editorial Intern

Paula Di Sessa Vavlis

Graphic Designer

Libro

\section{Language Editor}

Daniel de Almeida Leão 